\title{
ANALYSIS OF PROSPECTIVE PHYSICS TEACHERS' FEEDBACK ON ONLINE PEER-ASSESSMENT IMPLEMENTATION
}

\author{
Khusaini* \\ Program Studi Pendidikan Fisika, Fakultas Matematika dan IImu Pengetahuan Alam, \\ Universitas Negeri Malang, Indonesia
}

Received: 28 August 2016. Accepted: 18 October 2016. Published: January 2017

\begin{abstract}
This study aimed to analyse prospective physics teachers' feedback during the implementation of online peer-assessment in Teaching Physics in English course. Twenty prospective physics teachers participated in this study. They were familiar with the use of smart phone in their daily life. They tend to communicate using social media such as WhatsApp application. The students have practiced in using paper based peerassessment in other courses, but they have not applied it in online method providing real time feedback and score. The implementation of online peer-assessment challenged the students to assess their peer objectively. The lecturers' feedback influence students' skills how to evaluate their peer performance. Several factors may influence the quality of students' online peer-assessment such as students' culture back ground, implementation of the online peer-assessment, and practicant's performance.
\end{abstract}

\section{ABSTRAK}

Studi ini bertujuan untuk menganalisis balikan dari mahasiswa calon guru fisika dalam pelaksanaan online peer-assessment dalam matakuliah Teaching Physics in English. Dua puluh mahasiswa calon guru fisika berpartisipasi dalam kegiatan penelitian ini. Mereka sudah terbiasa menggunakan smartphone dalam aktivitas sehari-hari. Mereka cenderung menggunakan akun jejaring sosial seperti aplikasi WhatsApp. Mahasiswa calon guru fisika tersebut sudah pernah menerapkan kegiatan penilaian sejawat secara tradisional dengan menggunakan lembar pengematan di matakuliah lain, akan tetapi mereka belum pernah menerapkan online peer-assessment yang menghasilkan skor penilaian dan balikan atau masukan yang secara langsung. Penerapan penilaian teman sejawat berbasis online ini memberikan tantangan bagi para mahasiswa untuk memberikan penilaian secara objektif. Balikan dari dosen mempengaruhi keterampilan mahasiswa dalam mengevaluasi teman sejawat mereka. Beberapa faktor yang mempengaruhi kualitas penilaian teman sejawat secara online dari mahasiswa calon guru fisika meliputi latar belakang sosial budaya mahasiswa, pelaksanaan kegiatan penilaian teman sejawat secara online, serta kualitas tampilan seorang practitioner di depan kelas.

(C) 2017 Jurusan Fisika FMIPA UNNES Semarang

Keywords: analysis; feedback; pre-service physics teachers; online peer-assessment

\section{INTRODUCTION}

Recently, prospective physics teacher have a global world challenge. This condition is supported by the rapid growth of Information and Communication Technology. The development of ICT with all the facilities offers a variety of facilities for humans in communicating

*Correspondence Address:

Jalan Semarang 5 Malang Indonesia 56145

E-mail: khusaini.fmipa@um.ac.id and activities. As part of the global community, prospective physics teacher should have adequate skills to face the future challenges. These challenges include the implementation of the ASEAN Economic Community (AEC). The implementation of the AEC gives consequences for the freedom of the incoming and outgoing flows of labor among ASEAN countries.

One of the provisions that must be had to face this challenge is the ability to teach physics in English. Teaching in English is not an easy 
matter for physics teacher candidates. Learning strategies, the selection of relevant topics, and the determination of the type of evaluation have an impact on the success of the students in teaching, of course it will be more impact if they have to prepare it in English.

The determination of effective evaluation type to measure the student's learning achievement is the main concern in this research. Applying effective and efficient assessment types is expected to enable optimal results in the implementation of learning. Theoretically, optimal results can be achieved if the students obtain an academic climate that supports and stimulates them to increas their competences. This academic climate is strived to be realized through the application of online peer-assessment.

Peer-assessment is part of formative assessment. This assessment is characterized by efforts of achieving the learning objectives and improving student achievement in Teaching Physics in English subject. The use of the assessment is also expected to improve the quality of learning and to enhance student participation in learning activities. Khusaini (2016) found that the use of online peer-assessment can increase the enthusiasm and participation of students in lectures. Student involvement in the peer-assessment activities is one of the new types of assessment implementations. This assessment allows students to increase their participation in learning activities as well as to increase their ability of self-evaluation (Dochy, Segers, \& Sluijsmans, 1999; Valle, Andrade, Palma, \& Hefferen, 2016).

The use of peer-assessment also has a positive impact in the development of student competence. Khusaini (2016) found that the ability of prospective physics teacher in the learning activities increased after receiving feedback from colleagues. This finding is supported by Topping (1999) who revealed that there is a positive impact of peer-assessment in improving students' learning achievement.

Online peer-assessment is part of the learning innovation that is supposed to be continuously improved. This innovation is characterized by the integrated use of ICT facilities in learning activities. The use of ICT tools allows positive impacts if applied appropriately. The use of ICT facilities can provide ease in giving feedback and improve the effectiveness of assessment activities to improve student achievement (Anderson, Healy, Kole, \& Bourne, 2013; Klein \& Kientz, 2013; Segedy; Kinnebrew; \&
Biswas, 2013; Berry, 2009).

The use of online assessments as a form of integration of ICT facilities in peer-assessment has been investigated by Wen and Tsai (2008) who reported the positive impact of the use of the model in assessment activities in mathematics teachers. They both found that the quality of teacher appraisal skills during the use of ICT facilities is significantly increased. However, there is a negative side effect of the use ICT in the learning process. The teacher's attitudes and perceptions of online peer-assessment usage have shown a decreased impact. It need a further investigation to find the reasons since the assessment skill is a crucial skill to be mastered by the teachers.

Implementation of online peer-assessment has several challenges to be considered. The greatest challenge is how to provide objective assessments in a well-known Indonesian environment with high solidarity and familial values. Assessment and objective feedback from students to their friends are expected to improve student achievement. This objectivity also gained the attention of Liu and Charles (2006) suggesting that good peer assessment activities should continue to maintain quality feedback by preventing some factors that might reduce objectivity. They found a possible factor in reducing the objectivity of peer assessment such as gender.

The feedback given by lecturers in developing the students' ability should also be considered in implementing online peer-assessment. The feedback should always get attention both in terms of strategies and time management to be adrresed. Various studies have shown that the teachers' feedback have a positif impact on students' learning motivation, students' understanding, as well as the quality of student behavior (Akalin \& Sucuoglu, 2015; Seevers, et al., 2014; McLaren, 2012; Auld, et al., 2010; Vojdanoska, et al., 2010; Conroy, et al., \& Vo, 2009; Brosvic \& Epstein, 2007; Brosvic, et al., 2005). The findings indicate that it is still important to invite lecturers in addition to giving students' right to assess their peers. Therefore, the purpose of this study is to provide an overview of the role of online peerassessment on prospective physics teachers' motivation. This study also aims to analyze the feedback and assessment provided by the students to each other; to provide important informations for researchers and practitioners who consider applying peer-assessment activities using popular ICT facilities such as WhatsApp 
or other social media applications; as well as to provide an overview of the importance of feedback in improving the ability of students in assessing and in improving their learning achievement.

\section{METHOD}

The study has used a qualitative approach. The data were collected from the recapitulation results of the communication flow that occurs during the online learning and online peer-assessment of Teaching Physics in English class. The recap of the communication result is then copied from the conversation via the WhatsApp application.

The number of respondents involved in this research activity is 20 prospective physics teacher. All the respondents involved are in the third year or in the sixth semester. They take this course as one of the preparations program before practicing the teaching experience in high school. All respondents have good English skills because they have followed the English course for physics. Some of the participants who take this course also take English for Physics course, which is a companion course to improve reading ability and explain some of the material of physics.

Respondents involved in the study consisted of two groups. The first group is the majority group (15 students) symbolized as participants $(P)$ who enroll in the faculty officially. While the second group (5 students) are students who are motivated to improve their teaching skills in English with the permission of the lecturers without registering in the faculty symbolized as Non-Participant group (NP). Analysis of the influence of gender is done by giving the symbol $\mathrm{F}$ for female and the symbol M for male. Gender analysis is expected to describe the effect of gender on online peerassessment.

Data collection using WhatsApp application is selected because it is widely used as a base program especially android smartphone. The WhatsApp application owned by the majority of students who have android based smart phones. They are accustomed to using this program to communicate. Assessment of students to their friend via WhatsApp application then implemented in the class group that has been previously established (Figure 1).

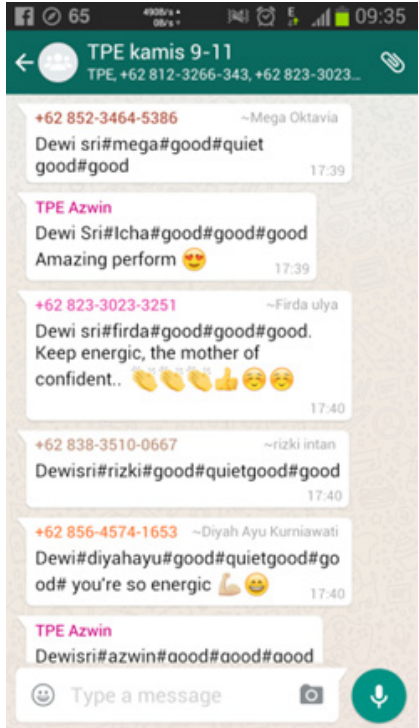

Figure 1. WhatssApp Group of Online PeerAssessment in Teaching Physics in English (TPE) Class (Khusaini, 2016)

Assessments and feedback given by students to their peers have a certain format. The format is very simple and can be used all respondents quickly with the provision of assessment rubric (see Table 1). The respondents simply typed their score score against a certain point and then added a reply to the performance of their friend (Figure 1). The format used in this peer assessment activity is to write the name of the presenter \# name of appraiser \# score for content criteria \# score for communication clarity criteria \# score for interaction with the audience \# feedback or comments for the presentation of the presenter and suggestions for better performance. The format of this writing is quite simple and the respondent will be able to finish writing the format in just about a minute.

There are two basics information submitted before peer-assessment activity was done. First, students are given information of how to use the assessment rubric. Second, the students get information that the assessment does not affect the final value. Student participation in assessment activities is an exercise in evaluating peers in their class. Students are not required to do an assessment, but it is recommended to give an appraisal of their peers' performance. Assessment is done directly. Students have about five minutes to assess the performance of their friends. Any student who is present or who is absent still have ooprtunity to read the peer assessment results from performance inputs that is accompanied by feedback. 
Table 1. Assessment rubric used in online peer assessment activities

\begin{tabular}{|c|c|c|c|}
\hline Criteria & Less & Fair & Good \\
\hline Content $(30 \%)$ & $\begin{array}{l}\text { Less Comprehensive or } \\
\text { Having Misconception }\end{array}$ & $\begin{array}{l}\text { Quite Comprehensive } \\
\text { andNo Misconception }\end{array}$ & $\begin{array}{l}\text { Comprehensive and } \\
\text { No Misconception }\end{array}$ \\
\hline $\begin{array}{l}\text { Communication } \\
\text { Clarity }(30 \%)\end{array}$ & $\begin{array}{c}\text { Unclear Pronounciation } \\
\text { and Intonation } \\
\text { Using Less Appropriate } \\
\text { Word Choices }\end{array}$ & $\begin{array}{l}\text { Quite good Pronoun- } \\
\text { ciation and intonation } \\
\text { Using several appro- } \\
\text { priate word choices }\end{array}$ & $\begin{array}{l}\text { Quite good Pronoun- } \\
\text { ciation and intonation } \\
\text { Using several appro- } \\
\text { priate word choices }\end{array}$ \\
\hline $\begin{array}{l}\text { Interaction with the } \\
\text { audience }(40 \%)\end{array}$ & $\begin{array}{l}\text { Less keeping eye con- } \\
\text { tact } \\
\text { Less encouraging audi- } \\
\text { ence participation }\end{array}$ & $\begin{array}{l}\text { Several keeping eye } \\
\text { contact } \\
\text { Several encouraging } \\
\text { audience participation }\end{array}$ & $\begin{array}{c}\text { Most keeping eye } \\
\text { contact } \\
\text { Most encouraging } \\
\text { audience participation }\end{array}$ \\
\hline
\end{tabular}

Lecturers immediately read out the results of peer-assessment after the assessment entered the group. The lecturer gives feedback to the student's peformance and also to the assessment or feedback given by the stundents in the peer-assessment. Data of comparative assessment given by between the lecturer and students' peer-assessment were analyzed. The analysis was focus on the tendency of students to assess their peers in peer teaching practice activities. Quantitative and qualitative approach were used in this research. Quantitative descriptive was used to describe the tendency of students in assessing each other. Quantitative data is presented in the form of frequency of peer-assessment aspects. In addition, qualitative analysis in the form of depiction of assessment is done by explaining all the facts in a deeper description.

The data collected in this research is a recording of all conversations and ratings occurring during peer-assessment activities by using the WhatsApp application that has transcript conversation facilities can be sent to email. The results of these conversations are analyzed and so the patterns can be taken. The conversation is finally grouped based on the time of peer assessment to know the pattern based on time.

\section{RESULTS AND DISCUSSION}

The use of WhatsApp application in peer-assessment provides some convenience. Each respondent can directly respond both in the form of assessment and feedback on their peers' performance in the practice of peers teaching activity. The use of android application is effective and efficient due to the rapid flow of communication. Each student can find out the scores of ratings and feedback as quickly as possible. Examples of feedbacks and groups contained in this peer assessment activity can be seen in Figure 1. Rapid rewinding time can have a direct effect to both the performance and the practitioner. Both parties can learn together and improve learning outcomes.

In this study students are grouped into four time groups. Time grouping is expected to provide an overview of the effect of study time with student assessment capability. The groups are sequentially grouped February 25, 2016, March 3, 2016, March 10, 2016, and the March 17, 2016 group.The first assessment group (February 25, 2016) can be seen in Table 2. In this assessment group, four students conducted teaching practice.

In this first week, the lecturer introduced how to use the rubric in the assessment activity. Assessment rubric already sent in provious day by email. Although newly introduced assessment rubrics, the number of students giving the same assessment or similar to the lecturers' assessment has increased even though the trend sometimes goes up sometimes down. In preliminary practice, the number of assessment that is in line with the assessment of lecturers is still two two students and eventually up to reach nine students.

The number of participating performances also experienced ups and downs starting at least 15 people and at most 17 people consisting of a mixture of $\mathrm{P}$ group and NP group. This increase can not be determined to match the expected amount because there is no obligation to provide an assessment, peer-assessment is not included in the final grade value, and not all students use their own smartphone. An increase in student ratings that is similar to lecturer assessment is possible because of the 
Table 2. Recapitulation of the Implementation of the First Week

\begin{tabular}{|c|c|c|c|}
\hline Practiti-oner & $\begin{array}{l}\text { Input } \\
\text { Values }\end{array}$ & $\begin{array}{l}\text { Same } \\
\text { Values }\end{array}$ & Feedback and Comments \\
\hline$A(F)$ & $\begin{array}{l}16 \\
14 \mathrm{P} \\
2 \mathrm{NP}\end{array}$ & 2 & $\begin{array}{l}15 \text { students focus on one point, } 1 \text { student review all points } \\
4 \text { students less objective }\end{array}$ \\
\hline $\mathrm{B}(\mathrm{M})$ & $\begin{array}{l}16 \\
14 \mathrm{P} \\
2 \mathrm{NP}\end{array}$ & 6 & $\begin{array}{l}4 \text { students focus on } 1 \text { point, } 2 \text { students review only } 2 \text { points } \\
4 \text { female students less objektif } \\
2 \text { students less thorough to the content }\end{array}$ \\
\hline$C(F)$ & $\begin{array}{l}17 \\
14 \mathrm{P} \\
3 \mathrm{NP}\end{array}$ & 9 & $\begin{array}{l}\text { Comments focus only on } 1 \text { point } \\
1 \text { student less objective } \\
3 \text { tudents wrong use rubric }\end{array}$ \\
\hline $\mathrm{D}(\mathrm{M})$ & $\begin{array}{l}15 \\
13 P \\
2 N P\end{array}$ & 4 & $\begin{array}{l}\text { Many constructive suggestions from students } \\
5 \text { students less objective }\end{array}$ \\
\hline
\end{tabular}

reversal of each peer assessment read and discussed.

In this first week also found the element subjectivity performance that gives better value to his/her close friend. The identification of the objectivity is done when the practitioner does not give a satisfactory performance. Errors in using the rubrics also occur in this week's assessment. This error is because it is still the first week and the lack of research students in using the rubric. The mistakes of both practitioner and performance concepts in basic physics concepts can also be identified through this peer-assessment. So this assessment is also useful for improving students' understanding of the concepts of physics. Concept error can be indicated from the performance' maximum value to the wrong concepts of practitioner performance.

Students' feedback on the peformance of their peers has decreased in terms of the focus of the discussion in the points available in the rubric. In the first judgment, a student found a comment to all points in the rubric, while most focus on one point that is considered interesting. The pattern changed to two people commenting on two points of the rubric. Finally, all the student comments only focus one point that is considered important. The comments are more likely to motivate and compliment the performance of their friends as well as feedback for improvements to the next performance. This decrease is caused by not all students using their own smartphone. The second assessment group was conducted one week after the first group (March 3, 2016). Assessment analysis occurs in the second group can be seen in Table 3.
The phenomenon that occurs this week is slightly different. The second group experienced an increase in the same number of assessments as the lecturer's assessment. Students' comments are increasingly focused on points that are considered important. The number of participants involved in the assessment also increased. The least number of performances are 15 students, while the highest numbers are 18 students. Objectivity assessment of students is increasingly visible with marked suitability between performance with ratings and comments given by students with their peers' performance. The number of input comments is getting smaller as students tend to give judgment than comment. Students give comments only to give suggestions for better performance.

The improvement of the student's expertise in giving assessment to his colleagues is seen in this second week. This skill improvement is made possible by many things such as input and discussion by lecturers after the performance and discussion of the results of the assessment. The second factor is the learning process from the performance of practitioner in the first wave so that the second week practitioner performance improves and facilitates the peer assessment process. The challenge that is still visible and must be faced is still not fully all students use communication tools for assessment so that impact the assessment results.

The next assessment group is the third week group that was held on March 10, 2016. Implementation figures for this week can be seen in Table 4.

In this week, there is still no objectivity in the assessment. The cause of this inabili- 
Table 3. Recapitulation of the Implementation of the Second Week

\begin{tabular}{|c|c|c|c|}
\hline Practitioner & $\begin{array}{l}\text { Input } \\
\text { Values }\end{array}$ & $\begin{array}{l}\text { Same } \\
\text { Values }\end{array}$ & Feedback and Comments \\
\hline$E(F)$ & $\begin{array}{c}15 \\
13 P \\
2 \mathrm{NP}\end{array}$ & 12 & $\begin{array}{l}\text { Focus on one point } \\
\text { Give simple motivation by using emoticon. } \\
\text { Focus on interaction point }\end{array}$ \\
\hline$F(F)$ & $\begin{array}{l}17 \\
14 \mathrm{P} \\
3 \mathrm{NP}\end{array}$ & 10 & $\begin{array}{l}\text { Focus on one point } \\
\text { More improvement remarks }\end{array}$ \\
\hline$G(F)$ & $\begin{array}{c}17 \\
14 \mathrm{P} \\
3 \mathrm{NP}\end{array}$ & 17 & $\begin{array}{l}9 \text { feedback } \\
\text { Short comments } \\
\text { Perfect performance }\end{array}$ \\
\hline$H(F)$ & $\begin{array}{l}18 \\
15 P \\
3 N P\end{array}$ & $\begin{array}{c}11 \\
7 \text { mirip }\end{array}$ & $\begin{array}{l}9 \text { feedback } \\
\text { Short comments } \\
\text { There is word "rather" }\end{array}$ \\
\hline$I(F)$ & $\begin{array}{c}18 \\
15 \mathrm{P} \\
3 \mathrm{NP}\end{array}$ & 18 & $\begin{array}{l}8 \text { feedback } \\
\text { Short comments }\end{array}$ \\
\hline$J(M)$ & $\begin{array}{c}18 \\
15 \mathrm{P} \\
3 \mathrm{NP}\end{array}$ & 18 & $\begin{array}{l}12 \text { feedback } \\
\text { Comments in the form of motivation }\end{array}$ \\
\hline
\end{tabular}

Table 4. Recapitulation of Third Week Implementation

\begin{tabular}{cccl}
\hline Practitioner & $\begin{array}{c}\text { Input } \\
\text { Value }\end{array}$ & $\begin{array}{c}\text { Same } \\
\text { Value }\end{array}$ & Feedback and comments \\
\hline \multirow{3}{*}{$\mathrm{K}(\mathrm{M})$} & 14 & & All students give comments \\
& $12 \mathrm{P}$ & 5 & Few of them less objective \\
& $2 \mathrm{NP}$ & & \\
$\mathrm{L}(\mathrm{F})$ & 14 & & 13 students give comments \\
& $12 \mathrm{P}$ & 14 & \\
& $2 \mathrm{NP}$ & & \\
$\mathrm{M}(\mathrm{F})$ & 13 & & 9 feedback \\
& $13 \mathrm{P}$ & 13 & Short comments \\
& $0 \mathrm{NP}$ & & \\
$\mathrm{N}(\mathrm{F})$ & 13 & & 7 feedback \\
& $13 \mathrm{P}$ & 6 & Short comments \\
& $0 \mathrm{NP}$ & & Few of them less objective \\
& 11 & & 7 feedback \\
& $11 \mathrm{P}$ & 11 & Short comments \\
& $0 \mathrm{NP}$ & & \\
\hline
\end{tabular}

ty is the performance of practitioner who has not given the best performance will encourage students to act less objective in providing an assessment. Students tend to give better value to their close friends both male and female. This situation may be caused by Javanese cultural factors to emphasize brotherhood or feel uncomfortable if giving an assessment of their close friends. Gender factors are not very influential in the objectivity of this assessment. This objectivity factor can be generated by the display of assessment after the assessment is completed followed by the discussion by the lecturer.

Comments given in reverse to the performance of practitioner increasingly conical with the need for input to improve the performance. Student performances are more likely to provide input to the practitioners who are deemed necessary to improve one aspect of the student practitioner.

This fourth week assessment group is 
the last one. The number of practitioners was assessed by only one person. Notes during this assessment activity can be seen in Table 5 . In the last assessment activity it can be said that all students have improved quite well. Students give the same assessment as many as six people and have similarities with the assessment of lecturer' assessment. Objective factors in the assessment activities are well ordered. All of the student assessments commented on the students' performance. These comments tend to motivate and provide input for performance improvement.

Table 5. Recapitulation of Fourth Week Implementation (March 17, 2016)

\begin{tabular}{|c|c|c|c|}
\hline $\begin{array}{l}\text { Practi- } \\
\text { tioner }\end{array}$ & $\begin{array}{l}\text { Input } \\
\text { Value }\end{array}$ & $\begin{array}{l}\text { Same } \\
\text { Value }\end{array}$ & $\begin{array}{l}\text { Feedback and } \\
\text { Comments }\end{array}$ \\
\hline$P(p)$ & $\begin{array}{c}12 \\
12 \mathrm{P} \\
0 \mathrm{NP}\end{array}$ & 12 & $\begin{array}{c}12 \text { Comments } \\
\text { Motivate feedback } \\
\text { and suggestions for } \\
\text { improvement }\end{array}$ \\
\hline
\end{tabular}

Improving the assessment of the student performances is caused by several things. First, students are more observant in the assessment activities. Students have shown a critical way of thinking to assess student practitioners. Second, the feedback given by the lecturer to each student input can be used as an example for the student appraiser in the next week's assessment activity. Giving feedback from this appraiser also has a positive impact on the practitioner. The practitioners can know the shortcomings and advantages.

Based on the analysis of peer-assessment activities, it can be concluded that there is an increase in the ability of peer-assessment by respondents. Feedback from the lecturer has a positive impact on student appraisers and practitioners. This condition is in accordance with the findings of Akalin and Sucuoglu (2015) which found a positive influence on improving the characteristics and ability of students in learning. Several studies also reinforce the importance of appropriate feedback to improve learning achievement and change the behavior of prospective students (Auld et al., 2010) and teachers who attend training (Duchaine, et al., 2011). Similar findings regarding repatriation according to student shortcomings were also found by Nuryantini, et al. (2015). They were indicating an improvement in the learner's ability after receiving feedback in classroom action research using authentic assessment.
Feedback technique should also be considered to give a positive impact. Seevers, et al. (2014) found the need to give positive feedback in public, and to give negative ones personally to positively affect students. The importance of effective feedback was also highlighted by Conroy, et al. (2009) which emphasizes the importance of appropriate feedback to foster student potential. Vojdanoska, et al. (2010) also reinforces the notion of the importance of giving feedback to instill a better skill to learners.

This study found that direct feedback can have a positive effect in improving students' ability to assess and practice teaching. This finding is in contrast to Brosvic, et al. (2005) who found that direct feedback only provided repetition and acquisition skills alone. Brosvic and Epstein (2007), however, found that direct feedback has an excellent impact on a valuation process, especially a matter of multiple choices. The time choice as a learnable moment is a crucial marker of the importance of effective timing of feedback. Feedback development should be done to improve the role of assessment in support of student learning activities. The addition of audio visual means and responses to the feedback given by peers should be done in further research. McLaren (2012) found that more varied feedbacks with audio visual means and student attitudes toward feedback allow for better learning. This process of feedback and media interaction makes it possible to streamline the role of feedback in peer-assessment activities.

Cultural factors of student origin should also be considered. Solidarity culture and mutual respect for friends should be considered as well. This factor may affect the subjectivity of student as an assessor. The factor is then influenced by less than the maximum performance of a practitioner. A practitioner who performs teaching skills in English that are not so maximized can get the maximum value from a close friend. The influence of this culture is much greater than the gender factor of the performance and practitioner.

Concept errors in Physics can also be checked during online peer-assessment activities. The lecturer is easier to detect the mistake of the practitioner concept during the teaching practice. The mistake of the assessor' concept can be checked from their score and feedback. It became the perfect moment to provide improved student concepts through lecturer feedback (Akalin \& Sucuoglu, 2015; Conroy et al., 
2009; Brosvic \& Epstein, 2007).

\section{CONCLUSION}

Online peer-assessment activities shows a positif impact in the Teaching Physics in English learning. The prospective physics teacher get more opportunity to learn how to conduct assessment in physics learning. Their capabilities in assessments actvities were increase significantly by considering the lecturer' assessment in the learning process. Factors that influence the prospectice students' performance in peer-assessment activies include: Javanis cultural background, online process which enable the practitioner know who is her/his assessors, as well as the quality of the practitioner in front of class.

\section{REFERENCES}

Akalin, S., \& Sucuoglu, B. (2015). Effects of Classroom Management Intervention Based on Teacher Training and Performance Feedback on Outcomes of Teacher-Student Dyads in Inclusive Classrooms. Educational Sciences: Theory and Practice, 15(3), 739-758.

Anderson, L. S., Healy, A. F., Kole, J. A., \& Bourne, L. E. (2013). The clicker technique: Cultivating efficient teaching and successful learning. Applied Cognitive Psychology, 27(2), 222-234.

Auld, R. G., Belfiore, P. J., \& Scheeler, M. C. (2010). Increasing pre-service teachers' use of differential reinforcement: Effects of performance feedback on consequences for student behavior.Journal of Behavioral Education, 19(2), 169-183.

Berry, J. (2009). Technology support in nursing education: Clickers in the classroom. Nursing Education Perspectives, 30(5), 295-298.

Brosvic, G. M., \& Epstein, M. L. (2007). Enhancing learning in the introductory course. The Psychological Record, 57(3), 391.

Brosvic, G. M., Epstein, M. L., Cook, M. J., \& Dihoff, R. E. (2005). Efficacy of error for the correction of initially incorrect assumptions and of feedback for the affirmation of correct responding: Learning in the classroom. The Psychological Record, 55(3), 401.

Conroy, M. A., Sutherland, K. S., Snyder, A., Al-Hendawi, M., \& Vo, A. (2009). Creating a Positive Classroom Atmosphere: Teachers' Use of Effective Praise and Feedback. Beyond Behavior, 18(2), 18-26.

Dochy,F. Segers,M. Sluijsmans, D.(1999) The use of Self-,peer-, and Co-Assessment in Higher
Education: a Review. Studies in Higher Education, 24(3), 331-350.

Duchaine, E. L., Jolivette, K., \& Fredrick, L. D. (2011). The effect of teacher coaching with performance feedback on behavior-specific praise in inclusion classrooms. Education and Treatment of Children, 34(2), 209-227.

Khusaini.(2016).Online Peer-Assessment in Teaching Physics in English class for improving pre-service physics teachers learning. Makalah disajikan dalam 3rd International Conference on Research, Implementation and Education of Education of Mathematics and Science, FMIPA Universitas Negeri Yogyakarta, 16-17 Mei.

Klein, K., \& Kientz, M. (2013). A model for successful use of student response systems.Nursing education perspectives. 34(5), 334-338.

Liu, Ngar-Fun\& Carless, David.(2006).Peer feedback: the learning element of peer assessment. Teaching in Higher education, 11(3), 279-290.

McLaren, S. V. (2012). Assessment is for learning: supporting feedback. International Journal of Technology and Design Education, 22(2), 227-245.

Nuryantini, A. Y., Setiadi, T., Kurniawan, K., \& Farida, I. (2015). The Application Of Authentic Assessment With Feedback To Improve The Competence Of Mts 2 Bandung Students In Constructing A Scientific Report Of Motion Material In Science Learning. Jurnal Pendidikan Fisika Indonesia, 11(2), 108-116.

Seevers, M. T., Rowe, W. J., \& Skinner, S. J. (2014). Praise in public, criticize in private? An assessment of performance feedback transparency in a classroom setting. Marketing Education Review, 24(2), 85-100.

Segedy, J. R., Kinnebrew, J. S., \& Biswas, G. (2013). The effect of contextualized conversational feedback in a complex open-ended learning environment. Educational Technology Research and Development, 61(1), 71-89.

Topping, Keith .(1999). Peer Assessment between students in Colleges and Universities. Review of Educational research,68 (3),249-276.

Valle, C., Andrade, H., Palma, M., \& Hefferen, J. (2016). Applications of Peer Assessment and Self-Assessment in Music. Music Educators Journal, 102(4), 41-49.

Vojdanoska, M., Cranney, J., \& Newell, B. R. (2010). The testing effect: The role of feedback and collaboration in a tertiary classroom setting. Applied Cognitive Psychology, 24(8), 11831195.

Wen, M. L., \& Tsai, C. C. (2008). Online peer assessment in an inservice science and mathematics teacher education course. Teaching in Higher Education, 13(1), 55-67. 